\title{
INTEGRASI NILAI-NILAI ISLAM DALAM PERUSAHAAN
}

\author{
Lalu Suprawan \\ Institut Agama Islam Negeri (IAIN) Mataram
}

\begin{abstract}
Abstrak
Produksi mempunyai motif kemaslahatan, kebutuhan dan kewajiban. Perilaku produksi merupakan usaha seseorang atau kelompok untuk melepaskan dirinya dari kefakiran. Sehingga, tujuan produksi dalam Islam adalah untuk mencapai maslahah yang optimum bagi konsumen atau bagi manusia secara keseluruhan. Dengan maslahah yang optimum ini, maka akan dicapai falah yang merupakan tujuan akhir dari kegaiatan ekonomi sekaligus tujuan hidup manusia.
\end{abstract}

Kata Kunci: Produksi, Nilai-nilai Islam

\section{A. PENDAHULUAN}

Setiap masyarakat, terlepas dari idiologinya, pasti mempunyai mekanisme untuk mencapai tugas produktifnya yang rumit. Karena pada dasarnya, setiap individu memiliki kewajiban dan tanggung jawab dalam kerja atas dirinya sendiri shingga setiap hasil yang didapat dari pekerjaan itu adalah hak milik pribadinya yang mesti dijaga dan dihormati.

Islam memandang bahwa setiap individu memiliki tanggung jawab untuk memelihara kehidupannya dari bahaya kelaparan, kehausan, kepanasan maupun kedinginan dan lain-lain. Seluruh keberadaan individu dalam Islam berusaha keras untuk pada setiap langkah berbuat selaras dengan nilai-nilai moral dan kerjasama dengan sesamanya demi mencapai tujuan keadaan bahagia baik secara moral maupun spiritual.
Namun, pada kenyataannya kebahagian multi dimensi ini sangat sulit diraih karena keterbatasan kemampuan manusia dalam memahami dan menerjemahkan keinginannya secara komprehensif, keterbatasan dalam menyeimbangkan antar aspek kehidupan, maupun keterbatasan sumber daya yang bisa digunankan untuk meraih kebahagian tersebut. $^{1}$

Dalam konteks inilah konsep Ekonomi Islam hadir sebagai sebuah Ilmu pengetahuan yang mengaplikasikan ajaran-ajaran dan atau aturan-aturan syariah yang mencegah ketidak adilan dalam pencarian dan pengeluaran sumbersumber daya guna memberikan kepuasan bagi manusia dan memungkinkan mereka melaksanakan kewajiban-kewajibannya kepada Allah dan masyarakat.

${ }^{1}$ Tim Penulis P3EI UII Yogyakarta, Ekonomi Islam, (Jakarta: PT. RajaliGrafindo Persada, 2008), 2. 
Karenaitu,Islamtidakmembatasi usaha-usaha untuk kemajuan material yang pasti dan sebagai suatu kondisi yang sangat diperlukan bagi evolusi pola sosial yang diharapkan. Ia mendesak orang supaya membuat semua usaha tercapai, ${ }^{2}$ karena proses konsumsi, produksi dan distribusi sebenarnya terpadu sedemikuan rupa, maka kemungkinan perbaikan simultan dalam suatu kehidupan material maupun spiritual menjadi mungkin adanya. ${ }^{3}$

Kajian ini merupakan salah satu upaya untuk menemukan pengaruh semangat Islam dalam aktivitas perusahaan yang difokuskan pada kegiatan produksi serta penggunaan alat teknologi sebagai salah satu upaya untuk efisiensi dan maksimalisasi hasil produksi. Dengan tujuan, kajian ini nantinya bisa memberikan tawaran makna efisiensi dalam penggunaan teknologi produksi yang dipengaruhi oleh semangat Islam.

\section{B. PEMBAHASAN}

\section{Pengertian}

Muhammad Rawwas Qalahji memberikan padanan kata "produksi" dalam bahasa Arab dengan kata al-intaj yang secara harfiyah dimaknai dengan ijadu sil'atin (mewujudkan atau mengadakan sesuatu) atau khidmatu mu'ayyanatin bi istikhdami muzayyajin min 'anashir al-intaj dhamina itharu

${ }^{2}$ M.N. Siddiqi, Aspek-Aspek Ekonomi I lam, Terj. Dewi P. Restiana (Solo: CV.Ramadani, 1991), 20.

${ }^{3}$ M.A. Manan, Teori dan Praktek Ekonomi I lam, Terj. M. Nastangin (Yogyakarta: PT. Dana Bakti Wakaf, 1997), 44. zamanin muhaddadin (pelayanan jasa yang jelas dengan menuntut adanya bantuan pengabungan unsur-unsur produksi yang terbingkai dalam waktu yang terbatas). ${ }^{4}$ Pandangan Rawwas di atas mewakili beberapa definisi yang ditawarkan oleh pemikir ekonomi lainnya.

Hal senada juga diutarakan oleh Abdurrahman Yusro Ahmad dalam bukunya Muqaddimah fi' $\mathrm{Ilm}$ alIqtishad al-Islamiy. menjelaskan bahwa dalam melakukan proses produksi yang dijadikan ukuran utamanya adalah nilai manfaat (utility) yang diambil dari hasil produksi tersebut. ${ }^{5}$ Produksi dalam pandangannya harus mengacu pada nilai utility dan masih dalam bingkai nilai "halal" serta tidak membahayakan bagi diri seseorang ataupun sekelompok masyarakat. Refleksi pemikiran tersebut disandarkan pada QS. Al-Baqarah [2]: 219 yang menjelaskan tentang pertanyaan dari manfaat memakai (memproduksi) khamr. ${ }^{6}$

Jadi, produksi adalah menciptakan manfaat dan bukan menciptakan materi. Maksudnya adalah bahwa manusia mengolah

${ }^{4}$ Muhammad Rawwas Qalahji, Mabahis $\mathrm{fi}$ al-Iqtishad al-Islamiy min Ushulihi al-Fiqhiyyah, (Beirut: Dar an-Nafes, 2000), Cet. ke-4, 62., dalam AM. Hasan Ali, Meneguhkan Kembali Konsep Produksi Dalam Ekonomi Islam, Makalah disampaikan pada Kuliah Informal Pemikiran Ekonomi Islam (KIPEI) pada tanggal 20 Maret 2004

${ }^{5}$ Abdurrahman Yusro Ahmad, Muqaddimah fi 'Ilm al-Iqtishad al-Islamiy, Iskandariyah, 1988, 39. dalam ibid.,

${ }^{6}$ "Mereka bertanya kepadamu tentang khamr dan judi. Katakanlah itu terdapat dosa besar dan beberapa manfaat bagi manusia, tetapi dosa keduanya lebih besar dari manfaatnya". (QS. Al-Baqarah [2]: 219. 
materi itu untuk mencukupi berbagai kebutuhannya, sehingga materi itu mempunyai kemanfaatan. Apa yang bisa dilakukan manusia dalam "memproduksi" tidak sampai pada merubah substansi benda. Yang dapat dilakukan manusia berkisar pada misalnya mengambilnya dari tempat yang asli dan mengeluarkan atau mengeksploitasi (ekstraktif). Memindahkannya dari tempat yang tidak membutuhkan ke tempat yang membutuhkannya, atau menjaganya dengan cara menyimpan agar bisa dimanfaatkan di masa yang akan datang atau mengolahnya dengan memasukkan bahan-bahan tertentu, menutupi kebutuhan tertentu, atau mengubahnya dari satu bentuk menjadi bentuk yang lainnya dengan melakukan sterilisasi, pemintalan, pengukiran, atau penggilingan, dan sebagainya. $^{7}$

\section{Faktor-Faktor Produksi}

Sampai sejauh ini memang belum ada kesepakatan di antara para ekonom muslim mengenai faktorfaktor produksi, karena baik al-Quran maupun Hadits tidak menerangkan masalah ini secara eksflisit tetapi hanya mengindikasikan. Perbedaaninimakin tajam ketika mereka membincangkan modal sebagai faktor produksi, karena apa bila modal mencakup sejumlah alat dan uang maka yang pertama akan menghasilkan sewa, dan yang disebutkan terakhir akan

${ }^{7}$ Husnul Khotimah, Teori Produksi dalam Islam, http://www.kafesyariah.net, akses 20 Juni 2009. menghasilkan bagi hasil dan resiko rugi bagi pemilik. ${ }^{8}$

Secara umum jika ketidak sepahaman dari kalangan ekonom muslim kontemporer tersebut di satukan maka akan menghasilkan enam faktor produksi, diantaranya:

a. Tanah dan segala potensi ekonomi, dianjurkan al-Quran untuk dikelola, dan tidak dpat dipisahkan dari proses produksi.

b. Tenaga kerja terkait langsung dengan tuntutan hak milik melalui produksi.

c. Modal, juga terlibat langsung dengan proses produksi karena pengertian modal mencakup modal produktif yang menghasilkan barang-barang yang dikonsumsi, dan modal individuyangdapatmenghasilkan kepada pemiliknya.

d. Manajemen karena adanya tuntutan leadership dalam Islam.

e. Teknologi

f. Materi atau bahan baku. ${ }^{9}$

\section{Tujuan Produksi}

Mekanisme pemanfaatan adalah tujuan badan usaha dalam ekonomi Islam. Pemanfaatan dalam pengertian sekarang mencakup pemanfaatan dari pengusahanya dan pemanfaatan dari pemilik modal. Dalam hal ini manajemen mislanya, tidak dapat menyisihkan sebagian pendapapatan dari perusahaan untuk kepentingan-

${ }^{8}$ Rustam Efendi, Produksi Dalam Islam, (Yogyakarta: Magistra Insani Press, 2003), 36.

${ }^{9} I b i d ., 38$ 
kepentingan sedekah (yang melampoi tingkat kemampuan minimum) tanpa terlebih dahulu meminta izin para pemilik modal lainnya. Beberapa macam tujuan produksi menurutM.N. Sidiqi yang terbit sekitar tahun 1972, menyebutkan lima tujuan produksi, yaitu:

a. Pemenuhan kebutuhankebutuhan sendiri secara wajar;

b. Pemenuhan kebutuhankebutuhan masyarakat;

c. Persediaan terhadap kemungkinan-kemungkinan di masa yang akan datang;

d. Persediaan bagi generasi yang akan datang;

e. Pemenuhan sarana bagi kegiatan sosial dan ibadah kepada Allah. ${ }^{10}$

\section{Produksi Dalam Islam}

Dalam ekonomi Islam, produksi mempunyai motif kemaslahatan, kebutuhan dan kewajiban. Perilaku produksi merupakan usaha seseorang atau kelompok untuk melepaskan dirinya dari kefakiran. Menurut Yusuf Qardhawi ${ }^{11}$, secara eksternal perilaku produksi dimaksudkan untuk memenuhi kebutuhan setiap individu sehingga dapat membangun

${ }^{10}$ Monzer Kahf, Ekonomi Islam: Telaah Analitik Terhadap Fungsi Sistem Ekonomi Islam, (Yogyakarta: Pustaka Pelajara, 1995), 38; akan tetapi dalam tulisannya yang lain M.N. Sidiqi juga menyebutkan kelima tujuan produksi tersebut di atas sebagai tujuan aktivitas ekonomi yang sempurna menurut Islam, lihat M.N. Sidiqi, Aspek-Aspek Ekonomi Islam, Terj. Dewi P. Restiana (Solo: CV.Ramadani, 1991), 15.

${ }^{11}$ Qardhawi,Yusuf. "Peran Nilai dan Moral dalam Perekonomian Islam,” (Jakarta: Rabbani Press, 1995) kemandirian ummat. Sedangkan motif perilakunya adalah keutamaan mencari nafkah, menjaga semua sumber daya (flora-fauna dan alam sekitar), dilakukan secara profesional (amanah \& itgan) dan berusaha pada sesuatu yang halal. Karena itu dalam sebuah perusahaan misalnya, menurut Metwally ${ }^{12}$ asumsi-asumsi produksi, harus dilakukan untuk barang halal dengan proses produksi dan paska produksi yang tidak menimbulkan kemadharatan. Semua orang diberikan kebebasan untuk melakukan usaha produksi.

Berdasarkan pertimbangan kemashlahatan (altruistic considerations) itulah, menurut Mannan $^{13}$, pertimbangan perilaku produksitidaksemata-matadidasarkan pada permintaan pasar (given demand conditions). Kurva permintaan pasar tidak dapat memberikan data sebagai landasan bagi suatu perusahaan dalam mengambil keputusan tentang kuantitas produksi. Sebaliknya dalam sistem konvensional, perusahaan diberikan kebebasan untuk berproduksi, namun cenderung terkonsentrasi pada output yang menjadi permintaan pasar (effective demand), sehingga dapat menjadikan kebutuhan riil masyarakat terabaikan.

Dari sudut pandang fungsional, produksi atau proses pabrikasi

${ }^{12}$ M.M. Metwally, A Behavioural Model of An Islamic Firm," Readings in Microeconomics: An Islamic Perspektif, (Malaysia: Longman, 1992), 131-138.

${ }^{13}$ M.A. Mannan, The Behaviour of The Firm and Its Objective in an Islamic Framework", Readings in Microeconomics: An Islamic Perspektif, (Malaysia: Longman, 1992), 120-130. 
(manufacturing) merupakan suatu aktivitas fungsional yang dilakukan oleh setiap perusahaan untuk menciptakan suatu barang atau jasa sehingga dapat mencapai nilai tambah (value added). Dari fungsinya demikian, produksi meliputi aktivitas produksi sebagai berikut; apa yang diproduksi, berapa kuantitas produksi, kapan produksi dilakukan, mengapa suatu produk diproduksi, bagaimana proses produksi dilakukan dan siapa yang memproduksi?s

Berikut akan dijelaskan sekilas mengenai ketujuh aktivitas produksi tersebut.

.a Apa yang diproduksi.

Terdapat dua pertimbangan yang mendasari pilihan jenis dan macam suatu produk yang akan diproduksi; ada kebutuhan yang harus dipenuhi masyarakat (primer, sekunder, tersier) dan ada manfaat positif bagiperusahan dan masyarakat (harus memenuhi kategori etis dan ekonomi)

b. Berapakuantitasyangdiproduksi; bergantung kepada motif dan resiko.

Jumlah pruduksi dipengaruhi dua faktor; intern dan ekstern; faktor intern meliputi; sarana dan prasarana yang dimiliki perusahan, faktor modal, faktor SDM, faktor sumber daya lainnya. Adapun faktor ekstern meliputi adanya jumlah kebutuhan masyarakat, kebutuhan ekonomi, market share yang dimasuki dan dikuasai, pembatasan hukum dan regulasi. c. Kapan produksi dilakukan.

Penetapan waktu produksi, apakah akan mengatasi kebutuhan eksternal atau menunggu tingkat kesiapan perusahaan.

d. Mengapa suatu produk diproduksi.

1) alasan ekonomi;

2) alasan sosial dan kemanusiaan;

3) alasan politik.

e. Dimana produksi itu dilakukan.

1) kemudahan memperoleh suplier bahan dan alat-alat produksi;

2) murahnya sumber-sumber ekonomi;

3) akses pasar yang efektif dan efisien;

4) biaya-biaya lainnya yang efisien.

f. Bagaimana proses produksi dilakukan: input- proses-out put-out come.

g. Siapa yang memproduksi; negara, kelompok masyarakat, individu.

\section{Penggunaan Teknologi Untuk Mencapai Efisiensi Dan Maksimalisasi Hasil Produksi}

Pengambilan manfaat setiap partikel dari alam semesta adalah tujuan idiologi umat muslim. Hal ini jelasmerupakankewajibankeagamaan bagi manusia terhadap dunia dan ia secara langsung bersumber pada pandangan Islam mengenai manusia dan alam semesta. Islam mengancang 
tujuan ini dengan dua sarana: ajaranajaran etik (akhlak) dan hukum. ${ }^{14}$

Sehingga, tujuan produksi dalam Islam adalah untuk mencapai maslahah yang optimum bagi konsumen atau bagi manusia secara keseluruhan. Dengan maslahah yang optimum ini, maka akan dicapai falah ${ }^{15}$ yang merupakan tujuan akhir dari kegaiatan ekonomi sekaligus tujuan hidup manusia. ${ }^{16}$

Bila kita cermati lebih jauh, menurut Imam al-Ghazali dalam bukunya yang terkenal Al-Mustasfa, maslahah didefinisikan sebagai ekspresi untuk mencari keuntungan (manfaah) atau menghilangkan sesuatu yang berbahaya (mudurra)". Lebih lanjut dia menjelaskan bahwa pada dasarnya maslahah adalah kelestarian tujuan shariah yang terdiri dari lima hal: preservation of religion, life, intellectual, posterity and property. Dia menyimpulkan dengan mengatakan: "jika kelima prinsip ini dapat dijaga kelestariannya maka menghasilkan maslahah akan tetapi jika tidak bisa dijaga kelestariannya akan menghasilkan mafsadah dan menghindarkan mafsadah itu adalah maslahah. ${ }^{17}$

${ }^{14}$ Monzer Kahf, Ekonomi..., 34

${ }^{15}$ Falah adalah kemuliaan, dan kemena gan, yaitu kemuliaan dan kemenangan dalam hidup di dunia dan akherat yang akan memberikan kebahagiaan hakiki bagi manusia. Lihat Tim Penulis P3EI UII Yogyakarta, Ekonomi..., 2.

${ }^{16} \mathrm{Ibid}$., 264.

${ }^{17}$ Untuk lebih jelasnya lihat Asyraf Wajdi Dusuki, Corporate Governance and Stakeholder Management: An Islamic Approach; dalam Mohad Daud Bakar \& Engku Rabiah Adawiah E A., Essential Readings In Islamic Finance, (Malaysia: CERT Publications Sdn. Bhd., 2008), 403
Maka, bila kita kaitkan dengan pemakaian teknologi produksi yang sejalan dengan konsep hukum Islam yang penuh dengan nilai hunisme dan etika, akan berinflikasi pada adanya pandangan yang berbeda terhadap harkat dan martabat manusia, hal ini akan memberikan pengaruh penggunaan teknologi yang tidak mengakibatkan mudarat pada manusia. Misalnya, dalam memandang kedudukan manusia, khususnya tenaga kerja, dengan kapital (financial capital). Dalam pandangna konvensional tenaga kerja dan kapital memiliki kedudukan yang setara dimana keduanya adalah substitusi sempurna. Penggunaan tenaga kerja sebagaimana penggunaan modal dapat saling menggantikan berdasarkan pertimbangan efisiensi dan produktiviats. ${ }^{18}$

Secara tidak langsung argumen di atas telah menggeser pemaknaan teknologi produksi dalam Islam. Hal ini sejalan dengan pemikiran Quraish Shihab yang mengatakan bahwa teknologi adalah ilmu tentang cara menerapkan sains untuk memanfaatkan alam sebagai kesejahteraan dan kenyamanan manusia. ${ }^{19}$ Jadi, apabila implementasi teknologi produksi yang digunakan oleh perusahaan mengakibatkan ketidak nyamanan bagi manusia

\footnotetext{
${ }^{18}$ Tim Penulis P3EI UII Yogyakarta, Ekon mi..., 264.

${ }^{19}$ Quraish Shihab, Pandangan al-Quran Te tang Ilmu Pengetahuan dan Teknologi, Makalah disampaikan pada Kongres Nasional al-Quran, UIR-ICMI Pekanbaru, 13-15 Juni 1994; dalam Rustam Efendi, Produksi..., 69.
} 
khususnya tenaga (eksploitasi upah buruh, pemutusan hubungan kerja, dan berbagai bentuk dehumanisasi kegiatan produksi). Maka, penggunaan teknologi tersebut tidak dibenarkan dalam pandangan ekonomi Islam.

Substitusi antara tenaga manusia/ tenaga kerja dengan kapital pada dasarnya dapat dibagi menjadi dua yakni: 1). Substitusi yang bersifat alamiah; 2). Substitusi yang bersifat paksaan. Menurut Munrokhim ${ }^{20}$ penggunaan teknologi produksi yang sesuai dengan prinsip ekonomi Islam hanya dapat terjadi ketika substitusi tenaga manusia dan kapital tersebut berada pada substitusi yang bersifat alami.

Lebih lanjut Munrohim menawarkan jenis teknologi produksi yang dapat digunakan dalam konteks teknologi produksi Islam adalah teknologi produksi konstan dalam arti bahwa teknologi yang digunakan adalah teknologi yang memanfaatkan sumber daya manusia sedemikian rupa sehingga manusia-manusia tersebut mampu meningkatkan harkat kemanusiaannya. Karenanya, permasalahan produksi bukanlah mencari teknologi berpoduksi sedemikian rupa sehingga memberikan keuntungan maksimum, melainkan mencari jenis output apa, dari berbagai kebutuhan manusia, yang bisa diproduksi dengan teknologi yang

${ }^{20}$ Disampaikan dalam kuliah terakhir pada Program Pascasarjana UIN Sunan Kalijaga Tgl 15 Juli 2009 dan untuk lebih jelasnya lihat Tim Penulis P3EI UII Yogyakarta, Ekonomi..., 271-300. sudah ada tersebut sehingga diperoleh maslahah maksimum.

\section{KESIMPULAN}

Nilai-nilai dan norma dalam berproduksi mengingatkan kita akan pentingnya memperhatikan; peringatan Allah akan kekayaan alam, bahwa bekerja sendi utama produksi, berproduksi dalam lingkaran yang halal, perlindungan kekayaan alam. Semuanya terangkum dalam satu pemahaman bahwa dalam Islam segala aktifitas hidup termasuk dalam ekonomi, hendaknya bermuara dan berujung pada upaya untuk mencari Keridhoan Allah. Begitu pula dalam melaksanakan aktifitas produksi dan penggunaan teknologi, tidak hanya berdasarkan pada aktifitas menghasilkan daya guna suatu barang belaka, melainkan sebagai upaya menjalankan tugas manusia sebagai khalifah di muka bumi ini. Islam tidak melarang penggunaan teknologi produksi selama teknologi produksi yang digunakan memanfaatkan sumber daya manusia sedemikian rupa sehingga manusia-manusia tersebut mampu meningkatkan harkat kemanusiaannya sebagai khalifah di muka bumi.

\section{DAFTAR PUSTAKA}

Ahmad, Abdurrahman Yusro, Muqaddimah fi ' $\mathrm{Im}$ al-Iqtishad al-Islamiy, Iskandariyah, 1988, 39. dalam AM. Hasan Ali, Meneguhkan Kembali Konsep Produksi Dalam Ekonomi Islam, Makalah disampaikan pada 
Kuliah Informal Pemikiran Ekonomi Islam (KIPEI) pada tanggal 20 Maret 2004

Dusuki, Asyraf Wajdi, Corporate Governance and Stakeholder Management: An Islamic Approach; dalam Mohad Daud Bakar \& Engku Rabiah Adawiah E A., Essential Readings In Islamic Finance, (Malaysia: CERT Publications Sdn. Bhd., 2008)

Efendi, Rustam, Produksi Dalam Islam, (Yogyakarta: Magistra Insani Press, 2003)

Khotimah, Husnul, Teori Produksi dalam Islam, http://www. kafesyariah.net, akses 20 Juni 2009.

Kahf, Monzer, Ekonomi Islam, Telaah Analitik Terhadap Fungsi Sistem Ekonomi Islam, (Yogyakarta: Pustaka Pelajara, 1995)

Mannan, M.A., "The Behaviour of The Firm and Its Objective in an Islamic Framework", Readings in Microeconomics: An Islamic Perspektif, (Malaysia: Longman, 1992)

Teoridan PraktekEkonomi Islam, Terj. M. Nastangin (Yogyakarta: PT. Dana Bakti Wakaf, 1997)
Metwally, M.M., "A Behavioural Model of An Islamic Firm," Readings in Microeconomics: An Islamic Perspektif, (Malaysia: Longman, 1992)

Qalahji, M.Rawwas, Mabahis fi alIqtishad al-Islamiy min Ushulihi alFiqhiyyah, (Beirut: Dar an-Nafes, 2000), Cet. ke-4, 62., dalam AM. Hasan Ali, Meneguhkan Kembali Konsep Produksi Dalam Ekonomi Islam, Makalah disampaikan pada Kuliah Informal Pemikiran Ekonomi Islam (KIPEI) pada tanggal 20 Maret 2004

Qardhawi, Yusuf, Peran Nilai dan Moral dalam Perekonomian Islam, (Jakarta: Rabbani Press, 1995)

Sidiqi, M.N., Aspek-Aspek Ekonomi Islam, Terj. Dewi P. Restiana (Solo: CV.Ramadani, 1991)

Shihab, Quraish, Pandangan al-Quran Tentang Ilmu Pengetahuan dan Teknologi, Makalah disampaikan pada Kongres Nasional alQuran, UIR-ICMI Pekanbaru, 13-15 Juni 1994; dalam Rustam Efendi, Produksi Dalam Islam, (Yogyakarta: Magistra Insani Press, 2003)

Tim Penulis P3EI UII Yogyakarta, Ekonomi Islam, (Jakarta: PT. RajaliGrafindo Persada, 2008) 